\title{
The Differences in Students' Creative Problem-Solving Ability with and without Realistic Mathematics Comic Video
}

\author{
Tetty Natalia Sipayung1*, Imelda ${ }^{2}$, Tatag Yuli Eko Siswono ${ }^{3}$, Masriyah ${ }^{4}$ \\ 1,2Department of Mathematics Education, Universitas Katolik Santo Thomas, Medan, Indonesia \\ ${ }^{3,4}$ Department of Mathematics Education, Universitas Negeri Surabaya, Surabaya, Indonesia
}

\section{ART I CLE INFO}

\section{Article history:}

Received September 22, 2021

Revised September 29, 2021

Accepted November 14, 2021

Available online November 25, 2021

\section{Kata Kunci:}

Kreatif, Pemecahan Masalah, Video

Komik

Keywords:

Creative, Problem Solving, Video Comic

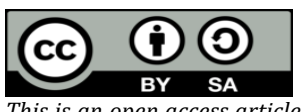

This is an open access article under the CC BY-SA license.

Copyright (C) 2021 by Author. Published by Universitas Pendidikan Ganesha.

\begin{abstract}
A B S T R A K
Prestasi matematika siswa di Indonesia masih lebih rendah dibandingkan siswa di negara lain. Hal ini disebabkan karena kemampuan kreativitas pada siswa masih rendah. Tujuan penelitian ini yaitu untuk menganalisis kemampuan kreatif pemecahan masalah siswa setelah menggunakan video komik matematika realistis. Jenis penelitian ini yaitu penelitian kuantitatif. Penelitian eksperimen kuasi dengan pretest postest comparison design ini dilakukan pada penelitian ini. Populasi penelitian ini adalah seluruh siswa kelas VII SMP yang terdiri atas empat kelas yang pararel. Pemilihan sampel dengan teknik random sampling sehingga terdapat dua kelas sampel penelitian yaitu sampel kelas kontrol dan sampel kelas eksperimen. Penelitian ini menggunakan instrument pretest dan posttest kemampuan pemecahan masalah kreatif. Pada penelitian ini data skor pretes dan posttest berdistribusi normal dan homogen. Berdasarkan analisis data hasil penelitian dengan menggunakan uji independent sampel $t$ test maka diperoleh keputusan bahwa terdapat perbedaan kemampuan pemecahan masalah kreatif siswa yang dibelajarkan dengan menggunakan video komik matematika realistik dengan kelompok siswa yang dibelajarkan dengan tidak menggunakan video komik matematika realistik. Jadi, disimpulkan kemampuan pemecahan masalah kreatif siswa yang dibelajarkan dengan menggunakan video komik matematika realistic lebih baik daripada yang tidak dibelajarkan dengan menggunakan video komik matematika realistik.
\end{abstract}

\section{A B S T R A C T}

Mathematics achievement of students in Indonesia is still lower than students in other countries. It is because the creative ability of students is still low. This study aimed to analyze students' creative problem-solving abilities after using realistic math comics videos. This type of research is quantitative research. A quasi-experimental study with a pretest-posttest comparison design was conducted in this study. The population of this study were all seventh-grade students of SMP, which consisted of four parallel classes. The sample was selected using a random sampling technique so that there were two classes of research samples, namely the control class sample and the experimental class sample. This study used a pretest and posttest instrument for creative problem-solving abilities. In this study, the pretest and posttest score data were normally distributed and homogeneous. Based on the research data analysis using the independent sample t-test, it was concluded that there were differences in the creative problem-solving abilities of students who were taught using real math comics videos with groups of students who were taught not to use fundamental math comics videos. So, it can be concluded that the creative problem-solving abilities of students who are taught using real math comic videos are better than those who are not taught using real math comic videos.

\section{INTRODUCTION}

Student creativity is one of the important educational goals. In the era of the Industrial revolution 4.0, students are expected to have more skills for their survival (Lestari et al., 2021; Oliveira et al., 2021). In addition, training to increase creativity is very important to improve the competitiveness of developed countries (Ayyildiz \& Yilmaz, 2021; Huang et al., 2020). Mathematics achievement of students in Indonesia is still lower than students in other countries (Anisa et al., 2019; Aritonang \& Safitri, 2021; Damayanti \& Sumardi, 2018). Therefore, in 21st century learning, students need to be taught core competencies which include critical thinking, creative thinking, communication skills, and collaboration to help students master content and solve problems related to their real lives (Churchill et al., 2013; Sa'pang \& Purbojo, 2020). The essential competence of the four competencies is creativity (Daggol, 2017; Istiq'faroh et al., 2020). Creative thinking skills are thinking processes that create new ideas widely and in various ways (Hidayat et al., 2018). Creativity is identical and related to the word innovation, both have different meanings and can be said to be different (Oliveira et al., 2021; Yang et al., 2018). Creative problem solving is a hallmark of higher intelligence and when it reaches its peak it can lead to the greatest progress (Kralik et al., 2016). 
In current conditions, procedural knowledge is part of creative thinking skills, and the decline of ideas, and declarative knowledge includes the domain level of one's knowledge task (Montag-Smit \& Maertz, 2017; Serbin et al., 2020). The creative thinking process also focuses on the cognitive activities involved in creativity (Fatah et al., 2016; Lassig, 2020). In the search for problem solving solutions, students are asked to find their own creative ideas and choose the most creative ideas (Aziza, 2019; Van Hooijdonk et al., 2020). The creative problem-solving model consists of the process of identifying unstructured problems, reconstructing a problem with data, and finding ideas and solutions for solving the problem (Kim et al., 2019). Creative thinking requires many of the same cognitive demands as other complex tasks (Kartika et al., 2019; Redifer et al., 2021).

The creative process includes internal cognition (e.g., judgment based on multiple choices) and external behavior (e.g., sketching possibilities) (Aljarrah, 2020; Rubenstein et al., 2019). The creative thinking process is also related to insight. Insights describe a problem solving process in which solutions usually come suddenly and after restructuring the understanding of the problem (Martinsen \& Furnham, 2019). Mental speed can be considered as the most basic cognitive ability that underlies higher-order cognitive functions to facilitate divergent thinking (Forthmann et al., 2019). Divergent thinking is currently the most widely used measure to assess creative thinking ability (Marliani, 2015; Wechsler et al., 2018). Convergent thinking is often contrasted with divergent thinking (creative idea formation), where there is no right answer but rather a large series of suitable, new, or interesting responses (Forthmann et al., 2019; Zabelina \& Silvia, 2020). Tasks involve divergent thinking, creative imagination, use of metaphors, transformation, and a number of other thinking skills relevant to creativity (Groyecka et al., 2020). Based on its origins and uses, creativity also reflects a kind of novelty or originality or shows something new and useful and comes into being (Aljarrah, 2020).

The development of student creativity is the teacher's additional responsibility and task (Hadar \& Tirosh, 2019; Soh, 2017). In psychology, the measurement of creativity is one of the most controversial issues (Segundo Marcos et al., 2020; Zabelina \& Silvia, 2020). In mathematics, tasks and activities asking students to perform procedures on a regular basis are opportunities for students to think, but this is not creative thinking (Hadar \& Tirosh, 2019). Creative thinking is a process of association and combination of elements (Cahyati et al., 2018; Segundo Marcos et al., 2020). Freudenthal expressed the notion of mathematics as a human activity. Mathematics must be connected to reality, stay close to children's experiences and relevant to society (Kartika et al., 2019; Sumirattana et al., 2017). Through this idea, the concept of realistic mathematics education (RME) emerged. RME can build students' mathematical cognitive knowledge at every stage of the creative thinking process that students go through (Sitorus \& Masrayati, 2016). Realistic mathematics education is also adopted in Indonesia which is called Indonesian realistic mathematics education. Students must develop skills to know when and how to apply mathematics in everyday life (Dooren et al., 2019).

Students must take responsibility for being part of the problem-solving process (Abu Bakar et al., 2018; Andini et al., 2018). The teacher's task is to arrange appropriate didactic situations in the form of problems in such a way that if students solve them, students will get the desired target of knowledge. When students accept problems as their own, teachers need to refrain from intervening and suggest how to complete assignments until students find answers to problems (Norqvist et al., 2019; Sari et al., 2020). One of the media that can also be used in the delivery of material is comics. In addition, a learning model is needed. It is hoped that the learning model leads to developing creativity and mathematical thinking skills which must depart from learning that makes students active (Ibrahim \& Widodo, 2020). In education, designing is establishing the focus and key points for teaching and learning as a process, usually with the aim of achieving certain learning outcomes (Jahnke et al., 2017; Wan Yunus \& Mat Ali, 2018).

Comics as a teaching tool with students as active constructors of comics (Aggleton, 2019; Gavaldon \& McGarr, 2019). Learning media in the form of cartoons are made with the aim that students do not get bored during the learning process (Saputri \& Qohar, 2020). Comics are visual media that are presented in the form of images (Hidayah \& Fathimatuzzahra, 2019; Lesmono et al., 2018). Comics as visual media are able to influence students' knowledge acquisition as a result of learning, because comics can attract students' interest and attention in receiving information (Cahyono et al., 2019; Tekle-Haimanot et al., 2016). Learning through e-comic characters is able to have a positive effect in motivating students to learn again (Hobri et al., 2021). In addition, it also motivates students to read, comic literature and also offers other benefits (Cahyono et al., 2019; Tekle-Haimanot et al., 2016).

Comics can be used as a learning approach (Rahajeng \& Muslimah, 2020). Comics are a combination of text and images. In comics there are also speech balloons that are part of the graphic style which plays an important role in showing the relationship between images and text. Speech balloons are considered a key element in comics (Aeni \& Yusupa, 2018; Karthika Devi et al., 2020). Media should be attractive because of innovative and innovative media. Interesting activities will encourage students to study with teachers 
(Harmawati et al., 2020; Karthika Devi et al., 2020). Besides comics, video is also a medium for delivering material. Video is a sequence of images that has a temporal dimension that individual images do not have (Li et al., 2020). Videos can focus teachers' attention on the complex interactions between learning content, their students' actions and the teacher's own actions that can be played over and over again. The concreteness of video images can invite teachers to make an analysis of teaching and learning of certain subjects (Brouwer et al., 2017).

In particular, participants acknowledged that more emotions were aroused during watching long videos than text (Tarchi et al., 2021). Textual translation of video text with meaningful sentences provides the potential to bridge the semantic relationship between video and language (Xiao \& Shi, 2020). Participants in conditions in which videos were statically segmented by images showed signifivantly better learning performance than those who watched videotapes non-stop or were shown static illustrations (Biard et al., 2018; Muhammad, 2018; Van Alten et al., 2020). If file size is an issue, videos can be hosted on Critical Commons or Google Drive and played directly from the internet. If the video is fully available on a platform such as YouTube or Netflix, the instructor can simply pause the video between segments and ask for response questions before continuing (Wooten, 2020). Participants who viewed videos on the topic of procedural knowledge in the presence of an instructor also had significantly higher levels of cognitive load (Wang et al., 2020). Previous research revealed that mobile learning (m-learning) had a positive effect on motivating students to learn mathematics (Cecep et al., 2019; Suprianto et al., 2019; Tetzlaff, 2017). The study also found a positive and significant relationship between mobile learning and the diversity of teacher training methods. Therefore, the idea emerged to design learning using other media, namely realistic mathematics comic videos, to analyze differences in the creative problem-solving abilities of groups of students who were taught using these media.

\section{METHOD}

The implementation of this quantitative research using a quasi-experimental method involves two groups, namely the group of students who are taught using realistic math comic videos and a group of students who are not taught using realistic math comics videos. This study uses a pretest posttest comparison design. This research was conducted at SMP Santo Yoseph Medan. The population of this study was all seventh-grade students of SMP Santo Yoseph Medan for the Academic Year 2020/2021 which consisted of four parallel classes, namely VII-A, VII-B, VII-C, and VII-D. Meanwhile, the research sample was all students of class VII-B as the sample of the experimental class and all students of class VII-C of junior high school as the sample of the control class. There are two variables in this study, namely the independent variable and the dependent variable. The learning method is the independent variable, while the creative problem-solving ability is the dependent variable. The research instrument used was a pretest and posttest of creative problem-solving abilities. The pretest grid can be seen in the following Table 1 .

Table 1. Creative Problem-Solving Ability Pretest Grid

\begin{tabular}{|c|c|c|c|c|c|c|c|c|c|c|}
\hline \multirow[b]{2}{*}{ No. } & \multirow{2}{*}{$\begin{array}{c}\text { Types of } \\
\text { Troublesh } \\
\text { ooting } \\
\text { Ability } \\
\end{array}$} & \multirow{2}{*}{$\begin{array}{c}\text { Types of } \\
\text { Creative } \\
\text { Thinking } \\
\text { Ability }\end{array}$} & \multirow[b]{2}{*}{ Indicator } & \multirow[b]{2}{*}{$\begin{array}{l}\text { Question } \\
\text { Number }\end{array}$} & \multicolumn{6}{|c|}{ Cognitive Level } \\
\hline & & & & & $\mathrm{C}_{1}$ & $\mathrm{C}_{2}$ & $\mathrm{C}_{3}$ & $\mathrm{C}_{4}$ & $\mathrm{C}_{5}$ & $\mathrm{C}_{6}$ \\
\hline 1. & $\begin{array}{l}\text { Understan } \\
\text { ding the } \\
\text { problem }\end{array}$ & & $\begin{array}{l}\text { Can identify and write } \\
\text { down what is known and } \\
\text { what is being asked. }\end{array}$ & $\begin{array}{l}1 a, 2 a \\
3 a\end{array}$ & & $\sqrt{ }$ & & & & \\
\hline \multirow[t]{3}{*}{2.} & $\begin{array}{l}\text { Planning } \\
\text { for }\end{array}$ & & $\begin{array}{l}\text { Planning a problem in } \\
\text { more ways than one. }\end{array}$ & & & & & & & \\
\hline & & Flexibility & $\begin{array}{l}\text { Able to change approach } \\
\text { or way of thinking. }\end{array}$ & $1 b, 2 b, 3 b$ & & & & & & $\sqrt{ }$ \\
\hline & (strategy) & Originality & $\begin{array}{l}\text { Develop unusual or } \\
\text { unusual plans. }\end{array}$ & & & & & & & \\
\hline \multirow[t]{3}{*}{3.} & $\begin{array}{l}\text { Solve } \\
\text { problems }\end{array}$ & Fluency & $\begin{array}{l}\text { Solve problems with more } \\
\text { than one answer. }\end{array}$ & & & & & & & \\
\hline & $\begin{array}{l}\text { according } \\
\text { the plan }\end{array}$ & & $\begin{array}{l}\text { Solve problems in various } \\
\text { or varied ways. }\end{array}$ & $1 c, 2 c, 3 c$ & & & & & & $\sqrt{ }$ \\
\hline & made & Originality & $\begin{array}{l}\text { Solve problems that are } \\
\text { different (unique) from the } \\
\text { usual. }\end{array}$ & & & & & & & \\
\hline
\end{tabular}




\begin{tabular}{|c|c|c|c|c|c|c|c|c|c|c|}
\hline \multirow[b]{2}{*}{ No. } & \multirow{2}{*}{$\begin{array}{c}\text { Types of } \\
\text { Troublesh } \\
\text { ooting } \\
\text { Ability }\end{array}$} & \multirow{2}{*}{$\begin{array}{c}\text { Types of } \\
\text { Creative } \\
\text { Thinking } \\
\text { Ability }\end{array}$} & \multirow[b]{2}{*}{ Indicator } & \multirow[b]{2}{*}{$\begin{array}{l}\text { Question } \\
\text { Number }\end{array}$} & \multicolumn{6}{|c|}{ Cognitive Level } \\
\hline & & & & & $\mathbf{C}_{1}$ & $\mathrm{C}_{2}$ & $\mathrm{C}_{3}$ & $\mathrm{C}_{4}$ & $\mathrm{C}_{5}$ & $\mathrm{C}_{6}$ \\
\hline 4. & $\begin{array}{l}\text { Recheck } \\
\text { answers }\end{array}$ & & $\begin{array}{l}\text { Re-check how to get the } \\
\text { answer or double-checking } \\
\text { whether there is another } \\
\text { more effective way to work } \\
\text { on the problem. }\end{array}$ & $\begin{array}{c}1 d, 2 d \\
3 d .\end{array}$ & & & & $\sqrt{ }$ & & \\
\hline
\end{tabular}

Table 2. Creative Problem-Solving Ability Posttest Grid

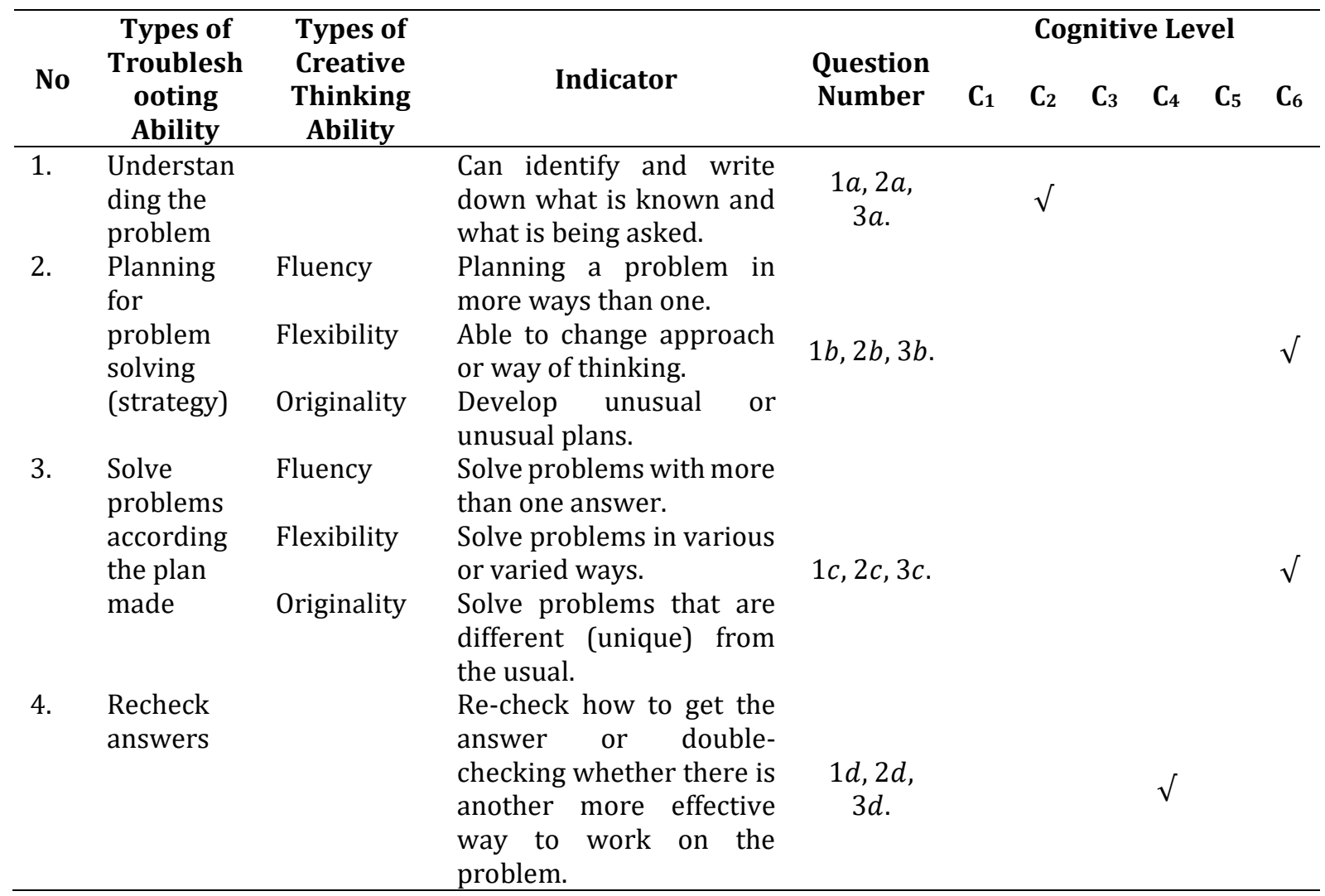

The sample of the research instrumen trial was eighth grade students of SMP Santo Yoseph Medan Academic Year 2020/2021. In this study, statistical data analysis was carried out, namely data prerequisite tests and research hypothesis testing. The analysis prerequisite test includes normality and homogeneity tests. To test the research hypothesis using the t test (difference test). However, before testing the research hypothesis, it has met the analytical requirements test, namely normal and homogeneous.

\section{RESULT AND DISCUSSION}

\section{Result}

\section{Data Analysis}

Before being treated with the learning method, a pretest was given to determine the initial creative problem-solving ability of the research sample students. After knowing the students' initial abilities, they were given treatment with different learning methods in the experimental class and the control class. The experimental class students applied the video-based learning method of realistic math comics, while the control class students applied learning without video-realistic math comics. The data on creative problemsolving abilities of 30 experimental class students based on the pretest results: an average of 56,67 and a standard deviation of 8,77 with a minimum score of 41,70 and a maximum score of 75,00. Meanwhile, based on the posttest results: the average is 84,59 and the standard deviation is 7,43 with a minimum score of 72,90 and a maximum score of 93,80 . In addition, the table above also states that the data on creative problem solving abilities of 32 control class students based on the results of the pretest: an average of 60,67 
and a standard deviation of 7,95 with a minimum score of 38,90 and a maximum score of 72,20. Meanwhile, based on the posttest results: the average is 75,72 and the standard deviation is 6,96 with a minimum score of 68,80 and a maximum score of 91,70 .

The prerequisite test was carried out on the pretest and posttest score data for the experimental class and the control class. Prerequisite tests include normality and homogeneity tests. The significance value of Asymp. Sig (2-tailed) is 0,348; 0,254; 0,357; and 0,205 is greater than 0,05 so that $\mathrm{H}_{0}$ is accepted and $\mathrm{H}_{1}$ is rejected. In accordance with the basis of decision making in the Kolmogorov-Smirnov normality test, it was concluded that the data were normally distributed. The value of pretest sig. ie. 0,209 and posttest $0,458>0,05$ then $\mathrm{H}_{0}$ is accepted and $\mathrm{H}_{1}$ is rejected or in other words that the data is homogeneous. This shows that the variance of the data pertest and posttest in the experimental class students and control class students is the same or homogeneous. To test the research hypothesis using the independent sample t test, which is to answer the suspicion of whether there are differences in students' creative problem-solving abilities given different learning methods or not. $t_{\text {count }}(4,583)>t_{\text {table }}(2,000)$ or sig. $\left(2\right.$-tailed) $<0,05$ then $\mathrm{H}_{0}$ is rejected and $\mathrm{H}_{1}$ is accepted, which means that there are differences in students' creative problem-solving abilities who are taught using math comic videos. realistic with students who do not use realistic math comic videos. The table above also shows the significant difference in the mean of the two groups. The average difference can also be seen in the following figure 1. It can be seen that the average creative problem-solving ability of the experimental class students is higher than the control group's ability.

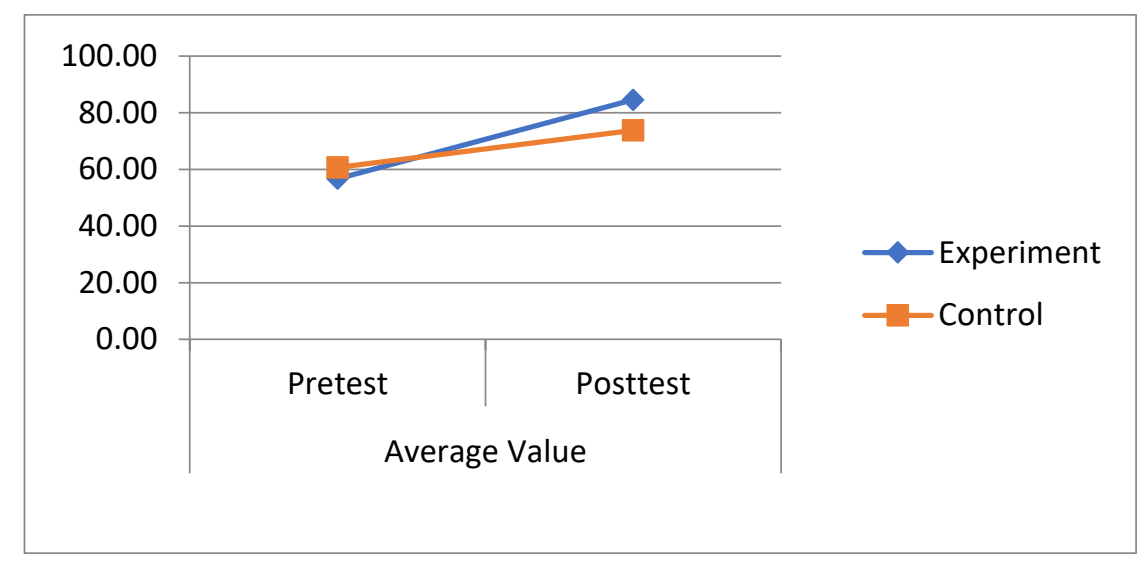

Figure 1. Graph of Average Pretest and Posttest Ability

\section{Discussion}

The research hypothesis test concluded that there were differences in the creative problem-solving abilities of groups of students who were taught with realistic mathematics comic videos and groups of students who were taught without using realistic mathematics comic videos. In other words, the creative problem-solving ability of the group of students who were taught with realistic mathematics comic videos was better than the group of students who were taught without reaistic mathematics comic videos. Learning videos are one of the learning media that can transmit messages and trigger students' thoughts and attention to encourage the learning process in students (Andriyani \& Suniasih, 2021; Kor et al., 2014; Van Alten et al., 2020). The developed video becomes a tool in the learning process. Learning will not run optimally (Leatherman \& Cleveland, 2020; Muhammad, 2018). The comic video developed provides audio and visuals to make it easier for students to reach. Other research also states that video media can increase students' interest in learning because students can listen and see pictures (Andel et al., 2020; Biard et al., 2018; Tarchi et al., 2021). Videos can present information, describe processes, explain complex concepts, teach skills, shorten or extend time, and influence attitudes. Videos can also be used for almost all topics, learning models, and every domain: cognitive, affective, and psychomotor. In addition, watching videos, after or before reading, can strengthen students' understanding of teaching materials.

Comics developed in the form of videos. Comics have short and exciting stories and are equipped with actions (Hobri et al., 2021; Taufiq et al., 2020). Comics can make the characters seem alive because they are accompanied by free colouring. Comics are simple, easy to catch and understand so that they are very popular with both children and adults. It causes students to be interested in learning (Hobri et al., 2019; Rahmata et al., 2020; Udayani et al., 2021). The advantage of the developed comics is that the presentation contains visual solid and story elements so that students can be emotionally involved when reading comics (Hobri et al., 2019; Lesmono et al., 2018). These results indirectly support the finding that mathematics e-comic has an effect on students' creative thinking skills (Hotbri, et al., 2021; Istiq'faroh et al., 
2020). In addition, it also support research findings which state that students' creative thinking processes can be explored by applying learning with realistic mathematics education (Sitorus \& Masrayati, 2016; Sumirattana et al., 2017). The uses of videos can increase students' creativity and problem-solving abilities which are part of creative problem-solving abilities (Gamboa, 2019; Yasunaga et al., 2020).

\section{CONCLUSION}

There are differences in creative problem-solving abilities between groups of students who are taught using realistic math comics videos and groups that are not taught using realistic math comics videos. The difference is significant where the ability of the experimental class students is higher than the ability of the control class students. It can be concluded that realistic math comic videos can improve students' creative abilities.

\section{ACKNOWLEDGEMENT}

The authors would like to thank you for your support and trust in the form of funding for a national competitive research grant, a collaborative research scheme between universities by the Ministry of Education, Culture, Research and Technology based on Decree Number 9/E1/KPT/2021 and Contract Agreement Number 165/LL1/PG/2021 between the Regional 1 Higher Education Service Institute and the Institute for Research and Community Service of Universitas Katolik Santo Thomas so that the authors can carry out this research well and publish the research results in this article.

\section{REFERENCES}

Abu Bakar, K. A., Noor, I. H. M., \& Dan Widodo. (2018). Nurturing nationalism character valuesat the primary schools in jayapura, papua. Cakrawala Pendidikan, 37(1), 42-56. https://doi.org/10.21831/cp.v37i1.13616.

Aeni, W. A., \& Yusupa, A. (2018). Model Media Pembelajaran E-Komik Untuk SMA. Jurnal Kwangsan, 6(1), 1. https://doi.org/10.31800/jurnalkwangsan.v6i1.66.

Aggleton, J. (2019). Defining digital comics: a British Library perspective. Journal of Graphic Novels and Comics, 10(4), 393-409. https://doi.org/10.1080/21504857.2018.1503189.

Agina, A. M. (2012). The Effect of Nonhuman's External Regulation on Young Children's Creative Thinking and Thinking Aloud Verbalization During Learning Mathematical Tasks. Computers in Human Behavior, 28(4), 1213-1226. https://doi.org/10.1016/j.chb.2012.02.005.

Aljarrah, A. (2020). Describing Collective Creative Acts in A Mathematical Problem-Solving Environment. $\begin{array}{llll}\text { Journal of Mathematical Behavior, } & 600819 .\end{array}$ https://doi.org/10.1016/j.jmathb.2020.100819.

Andel, S. A., de Vreede, T., Spector, P. E., Padmanabhan, B., Singh, V. K., \& Vreede, G. J. de. (2020). Do social features help in video-centric online learning platforms? A social presence perspective. Computers in Human Behavior, 113(April), 106505. https://doi.org/10.1016/j.chb.2020.106505.

Andini, S., Budiyono, \& Fitriana, L. (2018). Developing flipbook multimedia: The achievement of informal deductive thinking level. Journal on Mathematics Education, 9(2), 227-238. https://doi.org/10.22342/jme.9.2.5396.227-238.

Andriyani, N. L., \& Suniasih, N. W. (2021). Development Of Learning Videos Based On Problem-Solving Characteristics Of Animals And Their Habitats Contain in Science Subjects On 6th-Grade. Journal of Education, 5(1), 37-47. https://doi.org/10.23887/jet.v5i1.32314.

Anisa, A., Kodirun, K., Busnawir, B., \& Rahmat, R. (2019). Pengaruh Pengetahuan Dasar Matematika Terhadap Hasil Belajar Matematika Siswa Kelas X SMA Negeri 1 Lawa. Jurnal Pendidikan Matematika, 10(1). https://doi.org/10.36709/jpm.v10i1.5648.

Aritonang, I., \& Safitri, I. (2021). Pengaruh Blended Learning Terhadap Peningkatan Literasi Matematika Siswa. Jurnal Cendekia: Jurnal Pendidikan Matematika, 05(01), 735-743. https://doi.org/10.31004/cendekia.v5i1.555.

Ayyildiz, P., \& Yilmaz, A. (2021). 'Moving the Kaleidoscope' to see the effect of creative personality traits on creative thinking dispositions of preservice teachers: The mediating effect of creative learning environments and teachers' creativity fostering behavior. Thinking Skills and Creativity, 41. https://doi.org/10.1016/j.tsc.2021.100879.

Aziza, M. (2019). Kemampuan pemecahan masalah siswa dalam menyelesaikan soal tertutup dan terbuka pada pokok bahasan lingkaran. Pythagoras: Jurnal Pendidikan Matematika, 14(2), 126-138. 
https://doi.org/10.21831/pg.v14i2.26563.

Biard, N., Cojean, S., \& Jamet, E. (2018). Effects of Segmentation and Pacing on Procedural Learning By Video. Computers in Human Behavior, 89, 411-417. https://doi.org/10.1016/j.chb.2017.12.002.

Brouwer, N., Besselink, E., \& Oosterheert, I. (2017). The Power of Video Feedback with Structured Viewing Guides. Teaching and Teacher Education, 66, 60-73. https://doi.org/10.1016/j.tate.2017.03.013.

Cahyati, H., Muin, A., \& Musyrifah, E. (2018). Efektivitas Teknik SCAMPER dalam Mengembangkan Kemampuan Berpikir Kreatif Matematis Siswa. Journal of Mathematics Education IKIP Veteran Semarang, 2(2), 173. https://doi.org/10.31331/medives.v2i2.641.

Cahyono, A., Isnandar, \& Usodo, B. (2019). Implementation of Mathematical Comic on Exponent and Logarithms with 21st Century Skills - Oriented. Journal of Physics: Conference Series, 1211(1). https://doi.org/10.1088/1742-6596/1211/1/012078.

Cecep, Mutaqin, \& Pamungkas. (2019). Pengembangan Modul Quick Math Berbasis Mobile Learning sebagai Penunjang Pembelajaran Matematika di SMA. Prisma Sains: Jurnal Pengkajian Ilmu Dan Pembelajaran Matematika Dan IPA IKIP Mataram, 7(2). https://doi.org/10.33394/j-ps.v0i0.1761.

Churchill, D., King, M., \& Fox, B. (2013). Learning design for science education in the 21st century. Zbornik Instituta Za Pedagoska Istrazivanja, 45(2), 404-421. https://doi.org/10.2298/ZIPI1302404C.

Daggol, G. D. (2017). Lifelong learning: Not a 21st century, but an omnitemporal skill. International Journal of Social Humanities Sciences Research (JSHSR), 4(12), 1254-1267. https://doi.org/10.26450/jshsr.207.

Damayanti, H. T., \& Sumardi, S. (2018). Mathematical Creative Thinking Ability of Junior High School Students in Solving Open-Ended Problem. JRAMathEdu Journal of Research and Advances in Mathematics Education), 3(1), 36. https://doi.org/10.23917/jramathedu.v3i1.5869.

Dooren, W. Van, Lem, S., Wortelaer, H. De, \& Verschaffel, L. (2019). Improving realistic word problem solving by using humorTitle. The Journal of Mathematical Behavior, 53. https://doi.org/10.1016/j.jmathb.2018.06.008.

Fatah, A., Suryadi, D., Sabandar, J., \& Turmudi. (2016). Open-Ended Approach: An Effort In Cultivating Students' Mathematical Creative Thinking Ability And Self-Esteem In Mathematics. Journal on Mathematics Education, 7(1), 9-18. https://doi.org/10.22342/jme.7.1.2813.9-18.

Forthmann, B., Jendryczko, D., Scharfen, J., Kleinkorres, R., Benedek, M., \& Holling, H. (2019). Creative Ideation, Broad Retrieval Ability, And Processing Speed: A Confirmatory Study of Nested Cognitive Abilities. Intelligence, 75(June 2018), 59-72. https://doi.org/10.1016/j.intell.2019.04.006.

Gavaldon, G., \& McGarr, O. (2019). Exploring Pre-Service Teachers' Future Intentions to Use Technology Through The Use of Comics. Teaching and Teacher Education, 83, 99-109. https://doi.org/10.1016/j.tate.2019.04.004.

Groyecka, A., Gajda, A., Jankowska, D. M., Sorokowski, P., \& Karwowski, K. (2020). On The Benefits of Thinking Creatively: Why Does Creativity Training Strengthen Intercultural Sensitivity Among Children. Thinking Skills and Creativity, 37(February), 100693. https://doi.org/10.1016/j.tsc.2020.100693.

Hadar, L. L., \& Tirosh, M. (2019). Creative Thinking in Mathematics Curriculum: An Analytic Framework. Thinking Skills and Creativity, 33(September 2018), 100585. https://doi.org/10.1016/j.tsc.2019.100585.

Harmawati, D., Hasanah, N., Belwawin, S. M., \& Hidayat, S. H. (2020). Developing of an educative comic on the theme of clean and healthy life for grade 2 students of the elementary schools of YPPK Biankuk Merauke. Enfermería Clínica, 30(2). https://doi.org/10.1016/j.enfcli.2019.07.120.

Hidayah, I. N., \& Fathimatuzzahra. (2019). Development of Math Comic Learning Media on the Subject of Algebraic Expressions for Seventh Grade of Junior High School Students. Journal of Physics: Conference Series, 1227(1). https://doi.org/10.1088/1742-6596/1227/1/012029.

Hidayat, T., Susilaningsih, E., \& Kurniawan, C. (2018). The Effectiveness of Enrichment Test Instruments Design to Measure Students' Creative Thinking Skills and Problem-Solving. Thinking Skills and Creativity, 29, 161-169. https://doi.org/10.1016/j.tsc.2018.02.011.

Hobri, Adeliyanti, S., Fatekurrahman, M., Wijaya, H. T., Oktavianingtyas, E., Putri, I. W. S., \& Ridlo, Z. R. (2021). E-Comic Mathematics Based on STEAM-CC and its Effect on Students Creative Thinking Ability. Journal of Physics: Conference Series, 1839(1). https://doi.org/10.1088/17426596/1839/1/012036.

Hobri, Murtikusuma, R. P., \& Hermawan, L. I. (2019). Development of e-comic using pixton and kelase web on linear program of two variables assisted by geogebra. Journal of Physics: Conference Series, 1265, 012010. https://doi.org/10.1088/1742-6596/1265/1/012010.

Huang, N. tang, Chang, Y. shan, \& Chou, C. hui. (2020). Effects of Creative Thinking, Psychomotor Skills, and Creative Self-Efficacy on Engineering Design Creativity. Thinking Skills and Creativity, 37(March), 
100695. https://doi.org/10.1016/j.tsc.2020.100695.

Ibrahim, I., \& Widodo, S. A. (2020). Advocacy Approach With Open-Ended Problems To Mathematical Creative Thinking Ability. Infinity Journal, 9(1), 93. https://doi.org/10.22460/infinity.v9i1.p93102.

Istiq'faroh, N., Suhardi, \& Mustadi, A. (2020). Improving Elementary School Students' Creativity and Writing Skills Through Digital Comics. Elementary Education Online, 19(2), 426-435. https://doi.org/10.17051/ilkonline.2020.689661.

Jahnke, I., Bergström, P., Mårell-Olsson, E., Häll, L., \& Kumar, S. (2017). Digital Didactical Designs As Research Framework: iPad Integration in Nordic Schools. Computers and Education, 113, 1-15. https://doi.org/10.1016/j.compedu.2017.05.006.

Karthika Devi, M. S., Fathima, S., \& Baskaran, R. (2020). CBCS - Comic Book Cover Synopsis: Generating Synopsis of A Comic Book with Unsupervised Abstractive Dialogue. Procedia Computer Science, 172, 701-708. https://doi.org/10.1016/j.procs.2020.05.100.

Kartika, Y., Wahyuni, R., Sinaga, B., \& Rajagukguk, J. (2019). Improving Math Creative Thinking Ability by using Math Adventure Educational Game as an Interactive Media. Journal of Physics: Conference Series, 1179(1), 1-6. https://doi.org/10.1088/1742-6596/1179/1/012078.

Kim, S., Choe, I., \& Kaufman, J. C. (2019). The Development and Evaluation of The Effect of Creative ProblemSolving Program on Young Children's Creativity and Character. Thinking Skills and Creativity, 33(August), 100590. https://doi.org/10.1016/j.tsc.2019.100590.

Kor, H., Aksoy, H., \& Eerbay, H. (2014). Comparison of the Proficiency Level of the Course Materials (Animations, Videos, Simulations, E-Books) Used In Distance Education. Procedia - Social and Behavioral Sciences, 141(1). https://doi.org/10.1016/j.sbspro.2014.05.150.

Kralik, J. D., Mao, T., Cheng, Z., \& Ray, L. E. (2016). Modeling Incubation and Restructuring For Creative Problem Solving in Robots. Robotics and Autonomous Systems, 86, 162-173. https://doi.org/10.1016/j.robot.2016.08.025.

Lassig, C. (2020). A Typology of Student Creativity: Creative Personal Expression, Boundary Pushing and Task Achievement. Thinking Skills and Creativity, 36(April), 100654. https://doi.org/10.1016/j.tsc.2020.100654.

Leatherman, J. L., \& Cleveland, L. M. (2020). Student exam performance in flipped classroom sections is similar to that in active learning sections, and satisfaction with the flipped classroom hinges on attitudes toward learning from videos. Journal of Biological Education, 54(3), 328-344. https: //doi.org/10.1080/00219266.2019.1575266.

Lesmono, A. D., Bachtiar, R. W., Maryani, \& Muzdalifah, A. (2018). The instructional-based andro-web comics on work and energy topic for senior high school students. Jurnal Pendidikan IPA Indonesia, 7(2), 147-153. https://doi.org/10.15294/jpii.v7i2.14245.

Lestari, F. P., Ahmadi, F., \& Rochmad, R. (2021). The Implementation of Mathematics Comic Through Contextual Teaching and Learning to Improve Critical Thinking Ability and Character. European Journal of Educational Research, 10(1), 497-508. https://doi.org/10.12973/EU-JER.10.1.497.

Li, H., Cryer, S., Acharya, L., \& Raymond, J. (2020). Video and Image Classification Using Atomisation Spray Image Patterns and Deep Learning. Biosystems Engineering, 200(2014), 13-22. https://doi.org/10.1016/j.biosystemseng.2020.08.016.

Marliani, N. (2015). Peningkatan Kemampuan Berpikir Kreatif Matematis Siswa melalui Model Pembelajaran Missouri Mathematics Project (MMP). Formatif: Jurnal Ilmiah Pendidikan MIPA, 5(1), 14-25. https://doi.org/10.30998/formatif.v5i1.166.

Martinsen, Ø. L., \& Furnham, A. (2019). Cognitive Style and Competence Motivation in Creative Problem Solving. Personality and Individual Differences, 139(April 2018), 241-246. https://doi.org/10.1016/j.paid.2018.11.023.

Montag-Smit, T., \& Maertz, C. P. (2017). Searching Outside The Box in Creative Problem Solving: The Role of Creative Thinking Skills and Domain Knowledge. Journal of Business Research, 81(November 2016), 1-10. https://doi.org/10.1016/j.jbusres.2017.07.021.

Muhammad, H. M. (2018). Keefektifan Model Pembelajaran Tebak Kata Terhadap Hasil Belajar Pada Tema 7 "Indahnya Keragaman Di Negeriku" Siswa Kelas Iv. Mimbar Ilmu, 23(3), 200-207. https: //doi.org/10.23887/mi.v23i3.16436.

Norqvist, M., Jonsson, B., Lithner, J., Qwillbard, T., \& Holm, L. (2019). Investigating Algorithmic and Creative Reasoning Strategies by Eye Tracking. Journal of Mathematical Behavior, 55(April 2018), 100701. https://doi.org/10.1016/j.jmathb.2019.03.008.

Oliveira, A. W., Brown, A. O., Zhang, W. S., LeBrun, P., \& Eaton, L. (2021). Fostering creativity in science learning: The potential of open-ended student drawing. Teaching and Teacher Education, 105. https://doi.org/10.1016/j.tate.2021.103416. 
Rahajeng, I. M., \& Muslimah, F. (2020). Towards Safe Blood-Transfusion Practice for Nurses: Effectiveness of Comic-Based Learning Tool. Enfermeria Clinica, 30, 126-130. https://doi.org/10.1016/j.enfcli.2020.07.026.

Rahmata, A., Tuljannah, LaiRahmata, A., Tuljannah, L., Chotimah, S. C., \& Fiangga, S. (2020). Validitas E-Comic Matematika Berbasis Pemecahan Masalah pada Materi Kesebangunan. Jurnal Review Pembelajaran Matematika, 5(1), 53-65. https://doi.org/10.15642/jrpm.2020.5.1.53-65.

Redifer, J. L., Bae, C. L., \& Zhao, Q. (2021). Self-Efficacy and Performance Feedback: Impacts on Cognitive Load During Creative Thinking. Learning and Instruction, 71(June 2020), 101395. https://doi.org/10.1016/j.learninstruc.2020.101395.

Rubenstein, L. D. V., Callan, G. L., Ridgley, L. M., \& Henderson, A. (2019). Students' Strategic Planning and Strategy Use During Creative Problem Solving: The Importance of Perspective-Taking. Thinking Skills and Creativity, 34(October 2018), 100556. https://doi.org/10.1016/j.tsc.2019.02.004.

Sa'pang, A. W., \& Purbojo, R. (2020). Teacher`s self-efficacy, understanding of students` characters, and understanding of the 21st century skills as predictors of facilitator type of teaching style. Jurnal Psikologi Ulayat: Indonesian Journal of Indigenous Psychology, 7(2), 192-211. https://doi.org/10.24854/JPU108.

Saputri, R. R., \& Qohar, A. (2020). Development of Comic-Based Mathematics Learning Media on Social Arithmetic Topic. Journal of Physics: Conference Series, 1657, 012082. https://doi.org/10.1088/1742-6596/1657/1/012082.

Sari, M., Anggoro, B. S., \& Sugiharta, I. (2020). Analisis Peningkatkan Kemampuan Pemecahan Masalah Dan Kemandirian Belajar Dampak Flipped Classroom Berbantuan Video Pembelajaran. Nabla Dewantara, 5(2), 94-106. https://doi.org/10.51517/nd.v5i2.228.

Segundo Marcos, R. I., López Ferández, V., Daza González, M. T., \& Phillips-Silver, J. (2020). Promoting Children's Creative Thinking Through Reading and Writing in A Cooperative Learning Classroom. Thinking Skills and Creativity, 36(June 2019), 100663. https://doi.org/10.1016/j.tsc.2020.100663.

Serbin, K. S., Robayo, B. J. S., Truman, J. V., Watson, K. L., \& Wawro, M. (2020). Characterizing quantum physics students' conceptual and procedural knowledge of the characteristic equation. The Journal of Mathematical Behavior, 58. https://doi.org/10.1016/j.jmathb.2020.100777.

Sitorus, J., \& Masrayati. (2016). Students' creative thinking process stages: Implementation of realistic $\begin{array}{lllll}\text { mathematics } & \text { education. Thinking Skills and Creativity, } 22 .\end{array}$ https://doi.org/10.1016/j.tsc.2016.09.007.

Soh, K. (2017). Fostering Student Creativity Through Teacher Behaviors. Thinking Skills and Creativity, 23, 58-66. https://doi.org/10.1016/j.tsc.2016.11.002.

Sumirattana, S., Siriporn, M., \& Thipkongc, A. (2017). Using realistic mathematics education and the DAPIC problem-solving process to enhance secondary school students' mathematical literacy. Kasetsart Journal of Social Sciences, 8(3). https://doi.org/10.1016/j.kjss.2016.06.001.

Suprianto, A., Ahmadi, F., \& Suminar, T. (2019). The Development of Mathematics Mobile Learning Media to Improve Students' Autonomous and Learning Outcomes. Journal of Primary Education, 8(1), 84-91.

Tarchi, C., Zaccoletti, S., \& Mason, L. (2021). Learning From Text, Video, or Subtitles: A Comparative Analysis. $\begin{array}{llll}\text { Computers and } & 160 \text { (March } 2020), & 104034 .\end{array}$ https://doi.org/10.1016/j.compedu.2020.104034.

Taufiq, M., Wijayanti, A., \& Fajriah, E. (2020). The implementation of e-comic earth layer to enhance students' self-directed learning. Journal of Physics: Conference Series, 1567, 022070. https://doi.org/10.1088/1742-6596/1567/2/022070.

Tekle-Haimanot, R., Pierre-Marie, P., Daniel, G., Worku, D. K., Belay, H. D., \& Gebrewold, M. A. (2016). Impact of An Educational Comic Book on Epilepsy-Related Knowledge, Awareness, and Attitudes Among School Children in Ethiopia. Epilepsy and Behavior, 61, 218-223. https://doi.org/10.1016/j.yebeh.2016.05.002.

Tetzlaff, D. M. (2017). Using mobile technology to increase the math achievement and engagement of students with disabilities. Dissertation Abstracts International Section A: Humanities and Social Sciences, 3-A(E), No-Specified. https://doi.org/10.34917/11156827.

Udayani, N. K. R. T. K., Wibawa, I. M. C., \& Rati, N. W. (2021). Development Of E-Comic Learning Media On The Topic Of The Human Digestive System. Journal of Education Technology, 5(3), 472-481. https://doi.org/10.23887/jet.v5i3.34732.

Van Alten, D. C. D., Phielix, C., Janssen, J., \& Kester, L. (2020). Self-regulated learning support in flipped learning videos enhances learning outcomes. Computers and Education, 158(August), 104000. https://doi.org/10.1016/j.compedu.2020.104000.

Van Hooijdonk, M., Mainhard, T., Kroesbergen, E. H., \& van Tartwijk, J. (2020). Creative Problem Solving in Primary Education: Exploring The Role of Fact Finding, Problem Finding, and Solution Finding 
across Tasks. Thinking Skills and Creativity, 37(August 2019), 100665. https://doi.org/10.1016/j.tsc.2020.100665.

Wan Yunus, F., \& Mat Ali, Z. (2018). Attitude towards Learning Chemistry among Secondary School Students in Malaysia. Asian Journal of Behavioural Studies, 3(9), 63. https://doi.org/10.21834/ajbes.v3i9.61.

Wang, J., Antonenko, P., \& Dawson, K. (2020). Does Visual Attention To The Instructor in Online Video Affect Learning and Learner Perceptions? An Eye-Tracking Analysis. Computers and Education, 146, 103779. https://doi.org/10.1016/j.compedu.2019.103779.

Wechsler, S. M., Saiz, C., Rivas, S. F., Vendramini, C. M. M., Almeida, L. S., Mundim, M. C., \& Franco, A. (2018). Creative and Critical Thinking: Independent or Overlapping Components? Thinking Skills and Creativity, 27(November 2017), 114-122. https://doi.org/10.1016/j.tsc.2017.12.003.

Wooten, J. J. (2020). Integrating Discussion and Digital Media to Increase Classroom Interaction. International Review of Economics Education, 33(July 2019), 100174. https://doi.org/10.1016/j.iree.2020.100174.

Xiao, H., \& Shi, J. (2020). Video Captioning with Text-Based Dynamic Attention and Step-By-Step Learning. Pattern Recognition Letters, 133, 305-312. https://doi.org/10.1016/j.patrec.2020.03.001.

Yang, Z., Zhou, Y., Chung, J. W. Y., Tang, Q., Jiang, L., \& Wong, T. K. S. (2018). Challenge Based Learning Nurtures Creative Thinking: An Evaluative Study. Nurse Education Today, 71(September), 40-47. https://doi.org/10.1016/j.nedt.2018.09.004.

Yasunaga, T., Takase, K., Katsumura, M., Sakai, K., \& Shiota, S. (2020). Attempts at Learning Creative Problem-Solving in Remote Schools: Professional CPS Student Evaluation Using A Video Calling Application. International Journal of Information and Education Technology, 10(7), 547-551. https://doi.org/10.18178/ijiet.2020.10.7.1422.

Zabelina, D. L., \& Silvia, P. J. (2020). Percolating ideas: The Effects of Caffeine on Creative Thinking and Problem Solving. Consciousness and Cognition, 79(February). https://doi.org/10.1016/j.concog.2020.102899. 